\title{
Orthoptera assemblages of the relict meadows of the Szernye marsh area (West Ukraine: Transcarpathia)
}

\author{
Szabolcs Szanyi ${ }^{1}$ - Ludvig Potish ${ }^{2}$. István András Rácz ${ }^{3} \cdot$ Zoltán Varga $^{3} \cdot$ Antal Nagy $^{1}$
}

Received: 22 January 2020 / Accepted: 29 December 2020 / Published online: 10 May 2021

(C) The Author(s) 2021

\begin{abstract}
Orthoptera assemblages were sampled between 2012 and 2014 on six grasslands in marginal part of the former Szernye Marsh (Bereg Lowland, Transcarpathia, West Ukraine). 24 species in 1306 individuals were observed which is about the half of the Orthoptera species known from the Bereg Lowland. The bulk of the assemblages is formed by generalist chortobiont species (62.5\%), while thamnobionts, connected with tall forb and/or shrubby vegetation, also reach a relatively high frequency (29.1\%). According to the biogeographical composition, the Euro-Siberian species were predominating (58.3\%), combined with only scarce presence of West Palearctic and Mediterranean species. The multivariate analysis did not show any clear subdivision according to the a priori vegetation types with the exception of the xeric habitats. This assemblage type were characterised by a low species number (7-12) and very high frequency of one or at least two dominant species which were common in all types of studied habitats. Although their subdominant species differed from the other two assemlage types but they could not be referred as true character species. Thus the studied xeric habitats are not such true xeric grasslands as the sandy and saline grasslands of the Pannonian lowland. The main natural value of the area is preseved by semi-natural humide and transitional habitat types, which can be conserved by yearly alternating mowing and preserving the mosaic structure with some corridors among them.
\end{abstract}

Keywords Semi-natural habitats $\cdot$ Life forms $\cdot$ Faunal types $\cdot$ Indicator species $\cdot$ Assemblage types

\section{Introduction}

The Bereg Plain is the most northeastern part of the Pannonian lowland divided by the Hungarian-Ukrainian border. This area is a traditional low-input agricultural region scattered by several remnants of the natural and semi-natural habitats as lowland oak-hornbeam forests, hard- and softwood gallery

The authors declare that there was no need the permission for sampling of Orthoptera from "Velyka Dobron' game reserve".

Szabolcs Szanyi

szanyi.szabolcs@agr.unideb.hu

1 Faculty of Agricultural and Food Sciences and Environment Management, University of Debrecen, Institute of Plant Protection, P.O. Box 400, Debrecen 4002, Hungary

2 Faculty of Geography, Department of Forestry, Uzhhorod National University, st. Universytetska 14, Uzhgorod 88000, Ukraine

3 Faculty of Science and Technology, Department of Evolutionary Zoology, University of Debrecen, Egyetem tér 1, Debrecen 4032, Hungary forests which are often forming association complexes (Fekete and Varga 2006), forest clearings and humid meadows, but recently covered also by extended abandoned pastures and fallows. Thanks to some relatively undisturbed habitats it shelters numerous species which are protected in Hungary and even in EU level (Varga 1992). A considerable part of the area was belonged to a huge peatland called Szernye Marsh which existed here until the last decades of the XIX. century (Lakatos and Dalmay 1998). The climate of the Bereg lowland is cooler (yearly average $8.9^{\circ} \mathrm{C}$, mean of January $-3.4^{\circ} \mathrm{C}$ ) and more continental than the average of the Great Hungarian Plain. The average of the annual precipitation is also higher, about $620 \mathrm{~mm}$ (Baranyi 2009). The area belongs to the Pannonian biogeographical region as a whole with significant Carpathian influences in some groups of terrestrial invertebrates (e.g. land gastropods, ground beetles, moths, see: Varga 1992, 1995; Deli et al. 1997; Magura et al. 1997; Ködöböcz and Magura 1999; Gálik et al. 2001). Therefore, this area can be worthly designated as "Praecarpaticum", i.e. a transitional zone forming a dynamic, fluctuating connection between "Pannonicum" and "Carpathicum" (Varga 2003; Deli et al. 1995, 1997; Deli 
and Sümegi 1999). Similar situation was also observed in the Orthoptera, published in some earlier communications (Gallé and Gausz 1968; Nagy et al. 2011; Nagy et al. 2015). The first data on the Orthoptera of Transcarpathia were published at the end of the nineteenth century (Pungur 1899) and at the beginning of the twentieth century (Obenberger 1926; when the researched area was part of Czechoslovakia - 1918-1939). When Transcarpathia was part of USSR (1945-1991), research results from this territory were published in the 50's of the twentieth century by Likovitch $(1957,1959)$. As the habitats of the Bereg Plain are connected crossing the countrys' border, the researches should be extended also to the Transcarpathian side of the lowland which has probably closer connections to the Carpathians as it was already shown in ground beetles by Ködöböcz and Magura (1999).

The timeliness of such surveys is enhanced by the fact that large parts of Europe suffer from loss of biodiversity (e.g. May et al. 1995; Hambler and Speight 2004; Thomas et al. 2004; Thomas 2005). Especially in West- and Central European countries the current extinction of many species is considered as a consequence of habitat fragmentation and loss (Andrén 1996; Fahrig 1997) resulting from the destruction of natural and semi-natural habitats (Wilcox and Murphy 1985; Saunders et al. 1991; Harrison and Bruna 1999). Oppositely, in eastern part part of Central Europe the abandonment of traditional land use connected with social changes represents the major threat for biodiversity (Warren 1997; Baur et al. 2006; Wenzel et al. 2006; Schmitt and Rákosy 2007; Csergő et al. 2013).

Our focal area geographically belongs to the latter part of Europe where a significant fraction of biodiversity could survive in semi-natural and traditionally managed habitats till present. The target group of our surveys was Orthoptera, i.e. bush-crickets and grasshoppers, since they are known as sensitive indicator groups of naturalness of grassland habitats (Báldi and Kisbenedek 1997; Andersen et al. 2001) and were also often used in monitoring of changes of biodiversity in connection with land management regimes (Gardiner et al. 2005; O'Neill et al. 2003). Orthoptera can be considered as an optimal choice for conservation ecological surveys due to their moderate species richness, relatively easy sampling and identification of species, and also their responsiveness to vegetation changes (Henle et al. 1999; Maas et al. 2002). Their species and life form composition clearly reflects the structural characters of vegetation as cover, density and height (e.g. Morris 1969; Nagy 1991; Fielding and Brusven 1993; Rácz 1998a; Rácz 1998b; Rácz 1998c).

We carried out our surveys in a formerly faunistically insufficiently known area. Thus we had to make a pioneering survey concerning the species composition and diversity of Orthoptera assemblages. We were interested mostly in the following questions: i) Which are the main similarities vs. differences in the composition of assemblages in different grassland types? ii) Which are the indicator species of these assemblage types. iii) Which are the main life form and faunal types of the assemblages and how they reflect the habitat characteristics? iv) How can we protect or restore the conservation biologically significant (protected) species and species diversity of the grassland habitats?

\section{Material and methods}

\section{Sampling sites}

Our target area, the Velyka Dobron' Wildlife Reserve is extending on the marginal part of the former Szernye Marsh. Although this peatland was characterised by an exceptionally rich flora and valuable vegetation, it was nearly completely drained and replaced by arable lands (Fodor 1999). Thus, even the surveyed meadow habitats are mostly secondary or seminatural ones (Fig. 1).

On the basis of our preliminary results (Szanyi et al. 2015a) we characterised the sites as xeric ([i], [ii]), transitional ([iii], [v]) and humid ([iv], [vi]) type habitats (Table 1 and Figs. 2, 3 and 5).

[i] “Szapat" - $\left(48^{\circ} 26^{\prime} 05.56^{\prime} " \mathrm{~N} ; 22^{\circ} 23^{\prime} 50.52^{\prime \prime}\right.$ E) degraded dry pasture with periodically wet small depressions, irregularly grazed by cattle, surrounded by arable lands and mostly drained ditches. Dominant plant species are: Agrimonia eupatoria, Cichorium intybus, Lythrum salicaria, Ambrosia artemisiifolia, Arrhenatherum elatius, Daucus carota, Leontodon hispidus, Potentilla neumanniana.

[ii] "Körerdő" - $\left(48^{\circ} 25^{\prime} 50.21 " \mathrm{~N} ; 22^{\circ} 24^{\prime} 12.36^{\prime \prime}\right.$ E) semidry grassland between a mixed hardwood gallery forest (forest fringe with Melampyrum nemorosum) and arable lands surrounded by a drainage canal. Dominant plants of the semi-dry sward are: Arrhenatherum elatius, Calamagrostis epigeios, Agrimonia eupatoria, Cirsium arvense, Galium verum, Galium mollugo.

[iii] “Felső-erdő" - $\left(48^{\circ} 25^{\prime} 44.80^{\prime} \mathrm{N} ; 2^{\circ} 25^{\prime} 07.47^{\prime} \mathrm{E}\right)$ tall grass mesic-humid meadow with tall herbs and scrubs which is completely surrounded with hardwood gallery forest. Forest edge is overgrown with dominant Rubus caesius. Dominant plants of the sward are: Poa angustifolia, Cirsium arvense, Mentha arvensis, Symphytum officinale.

[iv] "Rezervátum I" - (48²5'16.62” N; 22²5'59.29" E) tall grass mesic-humid meadow bordered by hardwood gallery forest, some groups of willow scrubs and abandoned hayfields. Dominant plants are: Arrhenatherum elatius, Poa angustifolia, Juncus effusus, Convolvulus arvensis, Erigeron annuus, Lythrum salicaria. 
Fig. 1 Orthopterological sampling sites [i-vi] on the remains of the Szernye Marsh near Velyka Dobron' (West Ukraine). Black - sampling areas, dark grey - forest of Velyka Dobron' Wildlife Reserve, ligh grey - built-up area

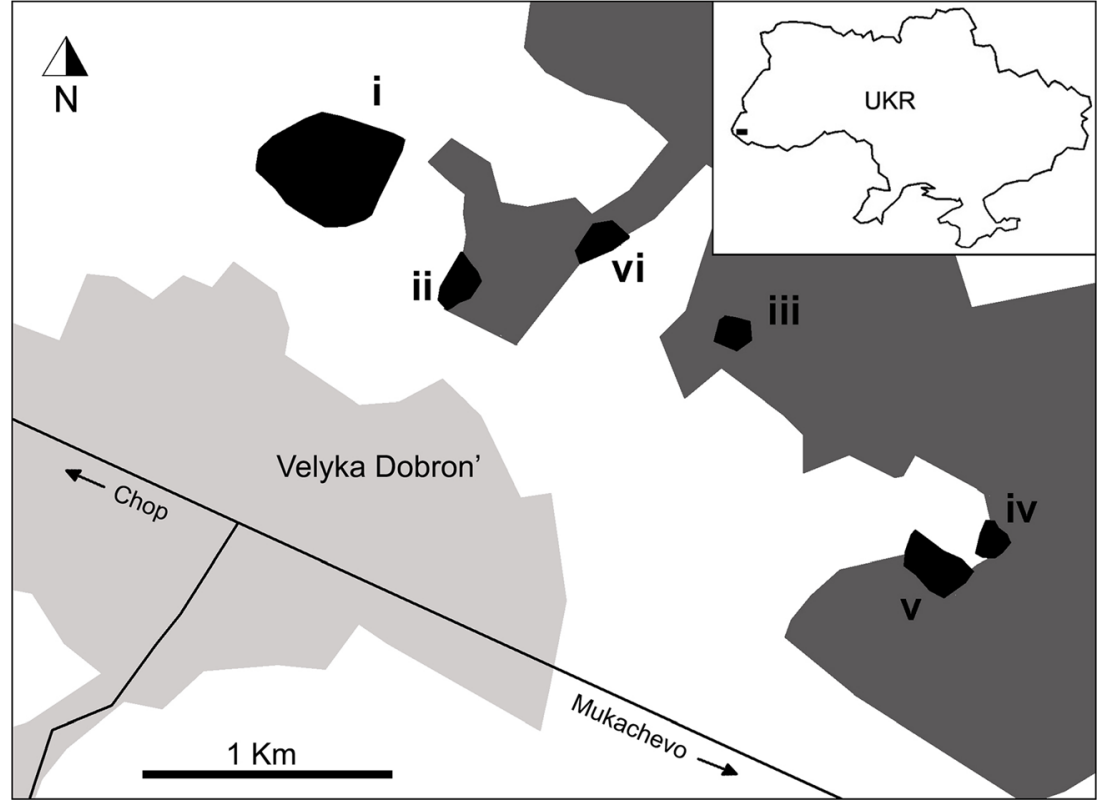

[v] “Rezervátum II" - $\left(48^{\circ} 25^{\prime} 13.53 ” \mathrm{~N} ; 22^{\circ} 25^{\prime} 48.93^{\prime \prime} \mathrm{E}\right)$ extended tall grass mesic-humid meadow surrounded by hardwood gallery forest and scrubs of Rubus fruticosus with abundant Melampyrum nemorosum. Dominant plants of the meadow are: Juncus effusus, Cirsium arvense, Erigeron annuus, Ranunculus acris, Solidago canadensis, Symphytum officinale, Galium aparine, Convolvulus arvensis.

[vi] "Kismakkos" - $\left(48^{\circ} 25^{\prime} 59.08^{\prime \prime} \mathrm{N} ; 22^{\circ} 24^{\prime} 43.14 "\right.$ E) mesic-humid meadow partly overgrown with scrubs of Rubus fruticosus and surrounded by hardwood gallery forest and black locust plantation. Dominant plants of the meadow are: Phleum pratense, Agrimonia eupatoria, Centaurea jacea, Galium aparine, Achillea collina, Lathyrus pratensis, Potentilla neumanniana, Ranunculus acris.

\section{Methods}

Orthoptera were sampled in July and August of 20122014, with 200 sweeps/sample used Ø $45 \mathrm{~cm}$ sweepnet, in $50 \times 50 \mathrm{~m}$ quadrates in more or less homogenous vegetation. The sampling was completed by $15-20$ min singing, visual and acoustical observation per sample (Nagy et al. 2007a, b). Sampled specimens were released after identification, except for some specimens which were preserved in $70 \mathrm{~V} / \mathrm{V} \%$ ethanol and were identified later in laboratory. The sampling was carried out usually in warm, sunny weather conditions between 10 a.m. and 5 p.m.. For the identification the books of Harz $(1957,1960)$ and the papers of Kis $(1962,1976,1978)$ were used. In nomenclature Nagy (2003), in the categorisation of faunal types and life form types Rácz (1998b) were followed.

\section{Statistics}

The composition of Orthoptera assemblages was compared by Principal Coordinate ( $\mathrm{PCoA}$ ) and cluster analysis in which the Bray-Curtis distance was used, in clustering the Ward-Orlóci (MISSQ) method was chosen (Tóthmérész 1996; Podani 1997a). The assemblages were compared using their yearly data sets containing relative abundance of species (RF\%). The analyses were carried out with the SynTax 2000 programme package (Podani 1997b). The assemblages were also characterised by the dominance rank structures of the samples.

Studied sites were a priori categorized to xeric, transitional and humid types on the basis of our preliminary results (Szanyi et al. 2015b). The correspondence between these a priori types and groups formed by multivariate analysis was evaluated. For the characterisation and comparison of assemblages their species richness, mean number of species and individuals and two types of Whittaker's index ( $\mathrm{S} / \alpha$ and its variant $\mathrm{S} / \alpha \max$ ) were used (Whittaker 1965).

Orthopterans can be divided into phytophilous and geophilous species (Bei-Bienko 1950; Pravdin 1978). The former group contains thamnobionts which are mainly bush-crickets connected with tall forb and shrubby vegetation and chortobionts, connected with dense grasslands. Oppositely, the geophilous (incl. Saxobiotic and psammobiotic) species need open rocky, gravel, sandy or saline patches. Beyond that there is a special group of fissurobionts and some species show transitional characteristics (Varga 1997; Rácz 2001; Nagy et al. 2008).

Species occurring in the Carpathian Basin and also in the Bereg lowland showed different biogeographical distribution and belong to different faunal types and groups as Continental s.l. containing Angarian and Siberian elements, and Southern s.l. formed by Mediterranean and African, etc. species. Thus 
Table 1 List of Orthoptera species sampled during 2012 2014 in the studied six habitats of the remains of Szernye Marsh (Velyka Dobron', West Ukraine) with their distribution, faunal and life form types

\begin{tabular}{|c|c|c|c|}
\hline Species & Distribution & Faunal type & Life form type \\
\hline \multicolumn{4}{|l|}{ Ensivera: Tettigonioidea } \\
\hline Phaneroptera falcata (Poda, 1761) & Eu-Sib & Sib-Pc & Th \\
\hline Leptophyes albovittata (Kollar, 1833) & $\mathrm{Eu}$ & Po-Med & Th \\
\hline Conocephalus discolor Fabricius, 1793 & Eu-Sib & Sib-Pc & Th \\
\hline Conocephalus dorsalis (Latreille, 1804) & Eu-W-As & Po-Ca & Th \\
\hline Ruspolia nitidula (Scopoli, 1786) & Af-Eu-Sib & Af & Th \\
\hline Tettigonia viridissima (Linnaeus, 1758) & Eu-Sib & Sib-Pc & Th \\
\hline Decticus verrucivorus (Linnaeus, 1758) & Eu-Sib & An & Ch-Th \\
\hline Metrioptera roeselii (Hagenbach, 1822) & $\mathrm{Eu}$ & Po-Ca & $\mathrm{Ch}$ \\
\hline Pholidoptera griseoaptera (De Geer, 1773) & $\mathrm{Eu}$ & Po-Ca & Th \\
\hline \multicolumn{4}{|l|}{ Ensifera: Grylloidea } \\
\hline Modicogryllus frontalis (Fieber, 1844)* & E-C-Eu, W-As & Po-Med & $\mathrm{Fi}$ \\
\hline Oecanthus pellucens (Scopoli, 1763) & $\mathrm{S}-\mathrm{Eu}$ & Po-Med & Th \\
\hline \multicolumn{4}{|l|}{ Caelifera: Acridoidea } \\
\hline Aiolopus thalassinus (Fabricius, 1781) & $\operatorname{Cos}$ & Af & $\mathrm{G}-\mathrm{Ch}$ \\
\hline Mecostethus parapleurus (Germar, 1817) & Eu-Sib & Ma & $\mathrm{Ch}$ \\
\hline Chrysochraon dispar (Germar, 1834) & Eu-Sib & An & $\mathrm{Ch}$ \\
\hline Euthistyra brachyptera (Ocskay, 1828)* & Eu-Sib & An & $\mathrm{Ch}$ \\
\hline Stenobothrus crassipes (Charpentier, 1825) & Eu-Sib & Po-Med & $\mathrm{Ch}$ \\
\hline Stenobothrus lineatus (Panzer, 1796) & Eu-Sib & An & $\mathrm{Ch}$ \\
\hline Omocestus rufipes (Zetterstedt, 1821) & Eu-Sib & An & $\mathrm{Ch}$ \\
\hline Chorthippus biguttulus (Linnaeus, 1758) & $\mathrm{Eu}$ & Po-Ca & $\mathrm{Ch}$ \\
\hline Chorthippus brunneus (Thunberg, 1815) & Eu-Sib & An & $\mathrm{Ch}$ \\
\hline Chorthippus dorsatus (Zetterstedt, 1821) & Eu-Sib & Sib-Pc & $\mathrm{Ch}$ \\
\hline Chorthippus oschei Helversen, 1986 & Eu-Sib & Sib-Pc & $\mathrm{Ch}$ \\
\hline Pseudochorthippus parallelus (Zetterstedt, 1821) & Eu-Sib & An & $\mathrm{Ch}$ \\
\hline \multicolumn{4}{|l|}{ Caelifera: Tetrigoidea } \\
\hline Tetrix bipunctata (Linnaeus, 1758) & $\mathrm{Pa}$ & Sib-Pc & $\mathrm{Ch}$ \\
\hline
\end{tabular}

Distribution and faunal types: Af - African, An - Angarian, C-Eu - Central European, Ca - Caspian, Car Carpathian, Cos - Cosmopolitan, Da - Dacian, En - Endemic, Eu - European, Eu-Sib - Euro-Siberian, Ho Holarctic, Ma - Mandzhurian, Med - Mediterranean, Pc Polycentric, Po-Ca - Ponto-Caspian, Po-Med - PontoMediterranean, S-Eu - South European, W-As - West-Asiatic, W-Pal - West-Palearctic; Life form types: Ch Chortobiont, Fi - Fissurobiont, G-Geobiont, Th - Thamnobiont, *known only from the Ukranian part of the Bereg lowland we characterised the studied Orthoptera assemblages both with the relative frequency of different life forms and faunal types (Rácz 1998c; Nagy 1991; Table 1).

The quantitative character species, (indicator species) of the assemblages were classified by the IndVal method, using the IndVal programme package (Dufrêne and Legendre 1997). We hierarchically classified the species according to their fidelity (constancy within group). The $I V$ value of species is the highest (100) if the given species is present in all samples of the given group and is also exclusive for this group of samples. The program calculates the $I V$ values of each species for each hierarchic level of clustering and the maximum value will be considered as indicator value of the given species. During analysis the hierarchy provided by former cluster analysis was used. The species with $I V$ value larger than 55 were considered as symmetric character species. The significance of $I V$ values was determined by randomisation (1000 iterations).

\section{Results}

During our three year survey (2012-2014) 24 Orthoptera species (11 Ensifera: 9 Tettigonioidea, 2 Grylloidea; 13 Caelifera: 12 Acridoidea, 1 Tetrigoidea; Tables 1 and 2) were sampled, which represents nearly half of the Orthoptera fauna occurring in the Hungarian part of the Bereg lowland (Nagy et al. 2015). The total number of sampled individuals was 1133 without unidentified larvae. Our check-list does not contain protected species although three species listed in Annex II Habitats Directive (Isophya stysi, Pholidoptera transsylvanica and 


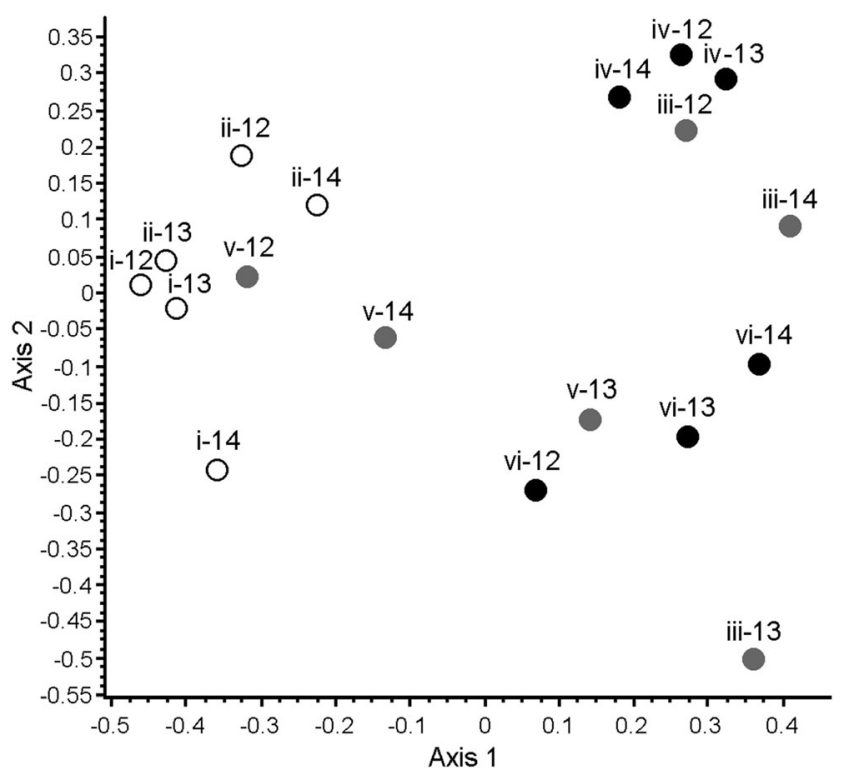

Fig. 2 Ordination $(\mathrm{PCoA})$ of the Orthoptera samples taken during the three-year study using Bray-Curtis index. Information content: $43.44+$ $20.39=63.83 \%$. Abbreviations consist of code of site and year of sampling (see Table 1). Colour of the markers show the a priori categories of sampling sites: empty dots - xeric, gray - transitional, black - humid habitats

Odontopodisma rubripes) were already found in other parts of the Bereg Lowland (Szanyi et al. 2015a). The abundance of Orthoptera assemblages (number of sampled individuals) showed extreme fluctuations in transitional ([iii], [v]) and one of the xeric ([i]) sites, and also a general decrease related to 2012. We found the lowest species numbers in the degraded xeric habitats ([i], [ii]) although similar trends in abundances could not be observed (Table 2).
Table 2 Number of Orthoptera species (S) and individuals $(\mathrm{N})$ in the six sites [i-vi] of the former Szernye Marsh area by studied years and in total

\begin{tabular}{|c|c|c|c|c|c|c|c|c|}
\hline \multirow[t]{2}{*}{ site } & \multicolumn{2}{|c|}{2012} & \multicolumn{2}{|c|}{2013} & \multicolumn{2}{|c|}{2014} & \multicolumn{2}{|c|}{ Total } \\
\hline & $\mathbf{S}$ & $\mathbf{N}$ & $\mathbf{S}$ & $\mathbf{N}$ & $\mathbf{S}$ & $\mathbf{N}$ & $\mathbf{S}$ & $\mathbf{N}$ \\
\hline [i]-x Szapat & 5 & 163 & 9 & 129 & 6 & 42 & 11 & 334 \\
\hline [ii]-x Körerdő & 3 & 99 & 4 & 25 & 9 & 47 & 10 & 171 \\
\hline [iii]-t Felső-erdő & 15 & 62 & 4 & 10 & 9 & 42 & 15 & 114 \\
\hline [iv]-h Rezervátum 1 & 7 & 65 & 7 & 48 & 7 & 32 & 10 & 145 \\
\hline [v]-t Rezervátum 2 & 12 & 125 & 11 & 34 & 12 & 58 & 18 & 217 \\
\hline [vi]-h Kismakkos & 7 & 96 & 7 & 21 & 11 & 35 & 14 & 152 \\
\hline Total & 20 & 610 & 17 & 267 & 16 & 256 & 24 & 113 \\
\hline
\end{tabular}

$\mathrm{x}$ : a priori xeric, t: a priori transitional, h: a priori humid

The composition of the assemblages showed striking differences. In the principal coordinate analysis ( $\mathrm{PCoA})$ the xeric and humid habitats were clearly separated along the first axis, which explains $43.44 \%$ of the variance (Fig. 2). Thus the main differences of assemblages are connected with the xeric ([i], [ii]) vs. mesic-humid (transitional: [iii], [v]; humid: [iv], [vi]) characters of their habitats. The differentiation of the transitional and humid habitats was more or less different in each year, e.g. the humid Rezervátum 1 [iv] had nearly the same position in each year while e. g. the transitional Felsö-erdö [iii] showed large differences along the second axis. Considering the a priori categories of sites and gradients of environmental conditions we expected that ordination will show a" horseshoe"-shaped pattern of the the samples. However, the results mostly did not confirm our expectations since the samples were only subdivided according to humidity (Fig. 2). The

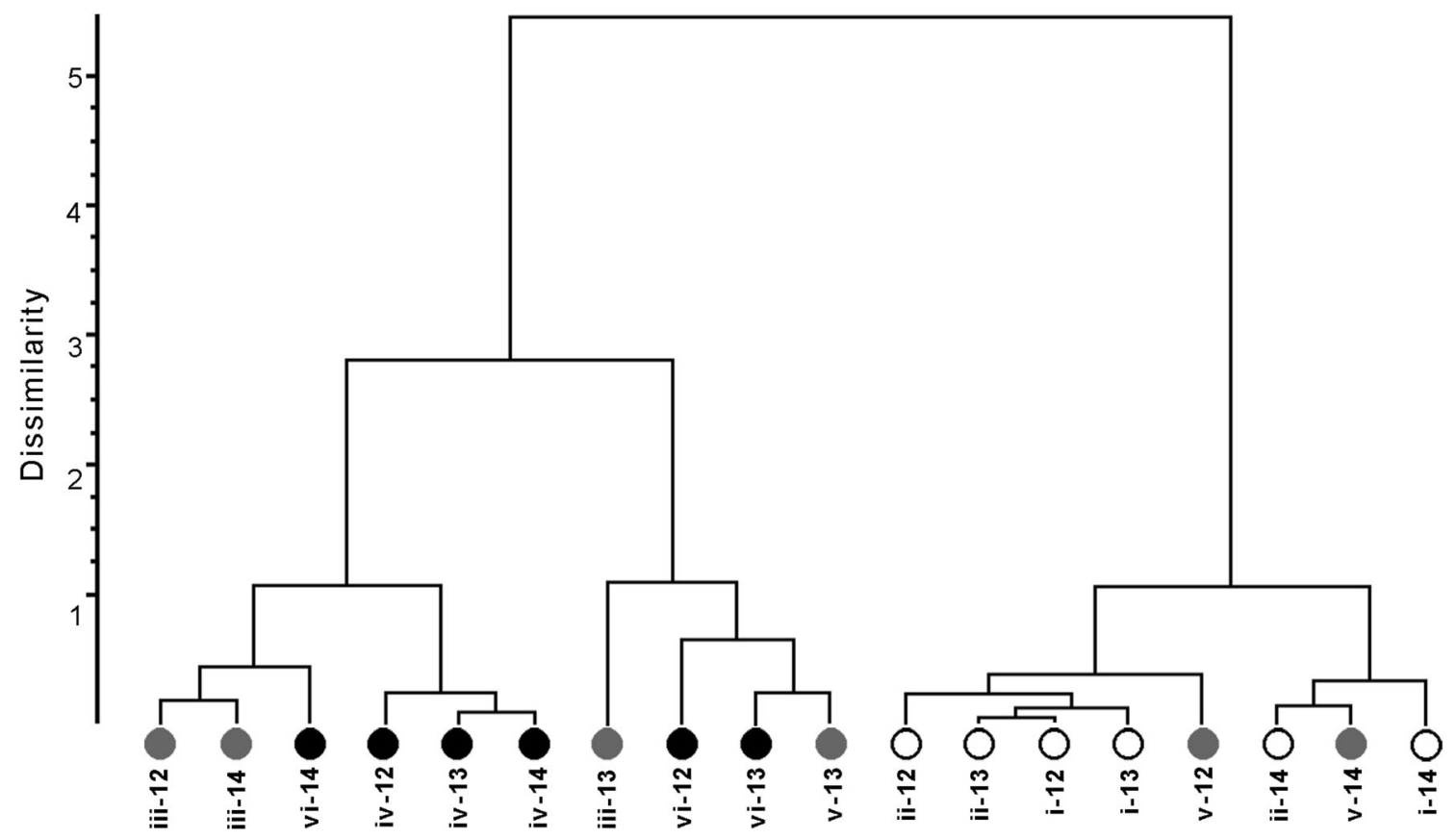

Fig. 3 Cluster analysis (Bray-Curtis, MISSQ) of the Orthoptera samples taken during 2012-2014 in Velyka Dobron'. For notations see Fig. 2 
samples of xeric habitats [i] and [ii] were consequently placed to the negative section of the first axis, associated with two samples of transitional [v] site. The other group, at the positive section of the first axis was more heterogenous and partly fluctuating ([iii]) according to the sampling years. The two humid sites [iv] and [vi] were clearly differentiated along the second axis. The cluster analysis has confirmed the grouping obtained by the ordination (Fig. 3).

We registered the changes of weather conditions during the sampling period and found remarkable differences between consecutive years. While in 2012 only the end of the summer was rather dry, in 2013 both July and August had some deficience of precipitation and in 2014 an unusual early summer drought was observed (Fig. 4). Although we could not statistically prove, it can be supposed that the shift of the transitional site Rezervátum 1 [v] in 2012 and 2014 to the xeric group was caused by these changes of weather conditions.

Assemblage types formed by multivariate analysis showed differentiation in their quantitative composition. The four most dominant species of the studied assemblages were Pseudochorthippus parallelus, Metrioptera roeseli, Leptophyes albovittata, Chorthippus dorsatus and Chorthippus oschei. Ranks of the dominant species of the humid and transitional samples were similar, four of the five species were same, while in case of xeric samples only two generally dominant species were ranked as one of the five most dominant species.

The indicator species of the assemblages were defined with the IndVal method. The species were hierarchically classified according to their specificity and fidelity within groups (Table 3). According to the clustering, we only found a single symmetric indicator species $(I V>55)$ (Chorthippus dorsatus) and also a not significant one (Chrysochraon dispar) of the humid and transitional group of samples. Three species were significantly characteristic especially for the humid group. The thamnobiont Pholidoptera griseoaptera and Ruspolia nitidula could be considered as symmetric character species, while the chorthobiont hygrophilous Mecosthetus parapleurus reached a significant $52.24 I V$ value. For the transitional group the thamnobiont Conocephalus discolor and the geo-chorthobiont
Aiolopus thalassinus were characteristic, that is in tune with the transitional character of these habitats. To the xeric group, we could not order any significant indicator species, only the chorthobiont, widely distributed Omocestus rufipes showed larger affinity to this habitat type. Some few widely distributed mostly mesophilous and meso-hygrophilous species were dominant in all surveyed grasslands (e.g. Metrioptera roeselii, Pseudochorthippus parallelus).

The species numbers were generally low in all sampling sites. However, samples belonging to the humid group showed the highest mean species number ( 10.17 species/site) which displays a sinking gradient to transitional and xeric ones (7.25 and 6.88 species/site, respectively). At the same time, we found also the lowest values of heterogenity according to the Whitakker indexes in the humid group of samples. Both types of Whitakker indexes supported the grouping of assemblages since the within-group heterogenity was in all cases lower than the between-group heterogenities (Table 4).

The life form and faunal type composition of different sample groups also showed characteristic differences. The average frequency of thamnobionts was the highest in those samples which were collected in transitional habitats with tall forb structures. Chortobiont species had the highest frequency in samples which were collected in such a priori xeric habitats where tall grasses and forbs only scarcely occurred (see: characterisation of the vegetation of the sampling sites; Table 4). The chorto-geobiont, geobiont and fissurobiont species were weakly represented. The biogeographical spectrum was dominated by some widely distributed Euro-Siberian species representing the cold-continental Angarian faunal type. Additionally, the balanced composition of the fauna with relatively high frequency of some few hygro-mesophilous southern species (Ruspolia nitidula, Metrioptera roeseli) can be explained by the biogeographically transitional status of the area. Some few African, Ponto-Mediterranean, Ponto-Caspian faunal elements also occurred in the samples (Tables 2 and 4).

The samples showed clearly different dominance rank structures (Fig. 5) with strong imbalance in case of a priori xeric habitats where one or two species were dominant and the
Fig. 4 Amount of precipitation in the vegetation period $(\mathrm{mm})$ by months in Velyka Dobron', 2012-2014

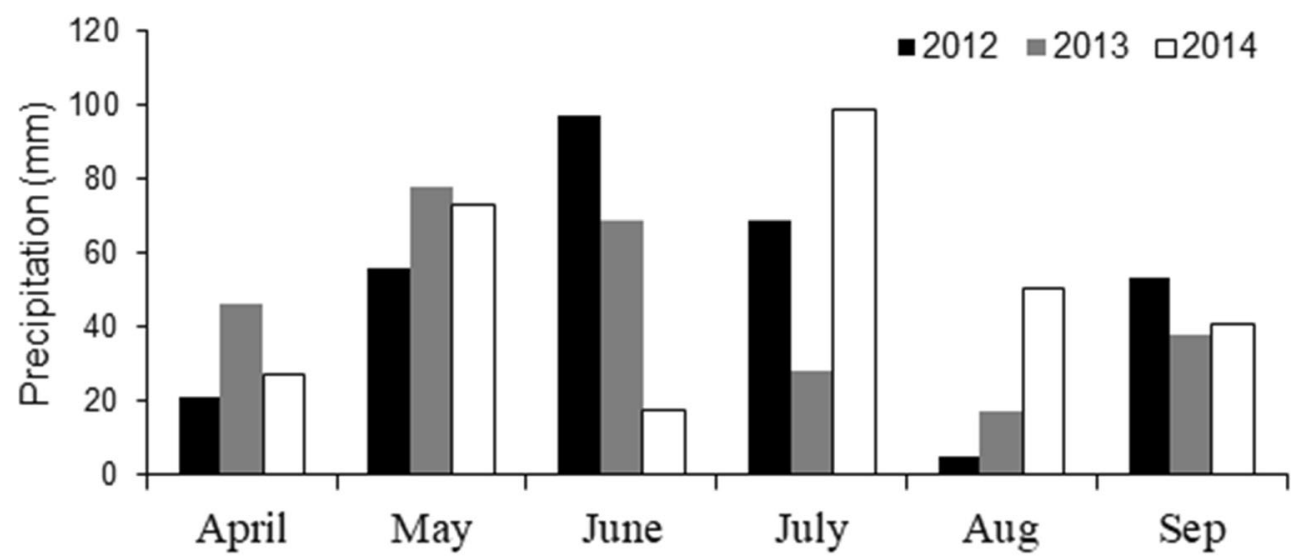


Table 3 Quantitative character species of the studied Orthoptera assemblage types with their indicator value $(I V>25)$

\begin{tabular}{llllll}
\hline Species & IndVal & Sign & Humid & Transitional & Xeric \\
\hline Pholidoptera griseoaptera & 79.12 & $* *$ & $24 / 5$ & $0 / 0$ & $2 / 1$ \\
Ruspolia nitidula & 64.96 & $* *$ & $33 / 6$ & $6 / 1$ & $11 / 4$ \\
Mecostethus parapleurus & 52.24 & $* *$ & $26 / 4$ & $5 / 1$ & $0 / 0$ \\
Chorthippus dorsatus & 67.08 & $* *$ & $50 / 4$ & $68 / 3$ & $4 / 2$ \\
Chrysochraon dispar & 42.87 & NS & $16 / 3$ & $23 / 2$ & $5 / 1$ \\
Conocephalus discolor & 69.51 & $* *$ & $12 / 4$ & $52 / 4$ & $29 / 4$ \\
Aiolopus thalassinus & 50.00 & $* *$ & $0 / 0$ & $9 / 2$ & $0 / 0$ \\
Chorthippus oschei & 42.67 & NS & $9 / 2$ & $80 / 2$ & $15 / 3$ \\
Pseudochorthippus parallelus & 94.44 & NS & $118 / 6$ & $42 / 3$ & $513 / 8$ \\
Metrioptera roeselii & 83.33 & NS & $174 / 6$ & $6 / 2$ & $103 / 7$ \\
Leptophyes albovittata & 66.67 & NS & $73 / 6$ & $56 / 2$ & $31 / 4$ \\
Phaneroptera falcata & 61.11 & NS & $42 / 5$ & $35 / 2$ & $20 / 4$ \\
Omocestus rufipes & 51.17 & NS & $4 / 2$ & $3 / 1$ & $27 / 5$ \\
Tetrix bipunctata & 38.94 & NS & $0 / 0$ & $3 / 1$ & $8 / 4$ \\
Oecanthus pellucens & 37.50 & NS & $0 / 0$ & $0 / 0$ & $6 / 3$ \\
Number of samples & & & 6 & 4 & 8 \\
\hline
\end{tabular}

Total number of sampled individuals and number of occupied samples in their group $\left(\mathrm{N}_{\text {total }} / \mathrm{n}_{\text {occ }}\right)$. **: IV value is significant at 0.05 level, NS: $I V$ is not significant other, few species had a very low frequency resulting in a geometric-like dominance-diversity curve (Magurran 1988). In the samples belonging to the other two a priori types the course of the frequency was mostly more balanced and showed log series or lognormal-like curves, with at least 3-4 dominant-subdominant species, especially in samples with the highest species number (iii-12: 15 spp., iv-12: 12 spp., v-14: $12 \mathrm{spp}$.). Surprisingly two of these species rich samples of a priori transitional sites [v-12, v-14] were grouped with samples of a priori xeric sites [i, ii]. This clearly contradicts to the fact that the structure of the latter assemblages was generally more stabilised.
Table 4 Mean relative

frequencies of life-form- and faunal types and measures of Whittaker's indexes in the studied Orthoptera assemblage types and in the complete data set, species numbers in assemblage types and in the complete data set

\begin{tabular}{|c|c|c|c|c|c|c|c|c|}
\hline \multirow[t]{2}{*}{ Habitat types } & \multicolumn{2}{|c|}{ Humid } & \multicolumn{2}{|c|}{ Transitional } & \multicolumn{2}{|l|}{ Xeric } & \multicolumn{2}{|l|}{ Total } \\
\hline & Mean & $\mathrm{SD}$ & Mean & $\mathrm{SD}$ & Mean & SD & Mean & SD \\
\hline \multicolumn{9}{|l|}{ Life-form types } \\
\hline Thamnobiont & 32.53 & 10.45 & 37.49 & 17.49 & 12.52 & 12.59 & 24.74 & 16.77 \\
\hline Chortobiont & 67.47 & 10.45 & 58.74 & 15.33 & 87.48 & 12.59 & 74.42 & 17.15 \\
\hline Geobiont & 0 & 0 & 2.3 & 2.98 & 0 & 0 & 0.51 & 1.59 \\
\hline Fissuribiont & 0 & 0 & 1.47 & 2.94 & 0 & 0 & 0.33 & 1.39 \\
\hline \multicolumn{9}{|l|}{ Faunal types } \\
\hline African & 5.5 & 2.86 & 3.86 & 5.92 & 1.4 & 2.33 & 3.31 & 3.78 \\
\hline Ponto-Caspian & 33.6 & 19.27 & 1.52 & 1.75 & 13.09 & 12.22 & 17.35 & 18.22 \\
\hline Ponto-Mediterranean & 12.22 & 8.18 & 16.7 & 19.68 & 4.61 & 7.74 & 9.83 & 11.78 \\
\hline Angarian & 24.99 & 25.45 & 17.06 & 5.84 & 71.26 & 19.35 & 43.79 & 31.6 \\
\hline Siberian-polycentric & 19.39 & 19.05 & 59.67 & 21.73 & 9.65 & 9.36 & 24.01 & 25.1 \\
\hline Mandzurian & 4.31 & 4.55 & 1.19 & 2.38 & 0 & 0 & 1.7 & 3.3 \\
\hline Continental s.l. & 48.69 & 18.59 & 77.92 & 18.77 & 80.9 & 18.57 & 69.5 & 23.17 \\
\hline Southern s. 1. & 51.31 & 18.59 & 22.08 & 18.77 & 19.1 & 18.57 & 30.5 & 23.17 \\
\hline Mean species number/site $(\alpha)$ & 10.17 & 3.13 & 7.25 & 2.87 & 6.88 & 3 & 8.06 & 3.23 \\
\hline Total species number $(\mathrm{S})$ & 18 & & 16 & & 17 & & 24 & \\
\hline Max. species number/site $(\alpha \max )$ & 15 & & 11 & & 12 & & 15 & \\
\hline Whittaker-index $\mathrm{S} / \alpha$ & 1.8 & & 2.2 & & 2.5 & & 3 & \\
\hline Whittaker-index $S / \alpha \max$ & 1.2 & & 1.5 & & 1.4 & & 1.6 & \\
\hline
\end{tabular}



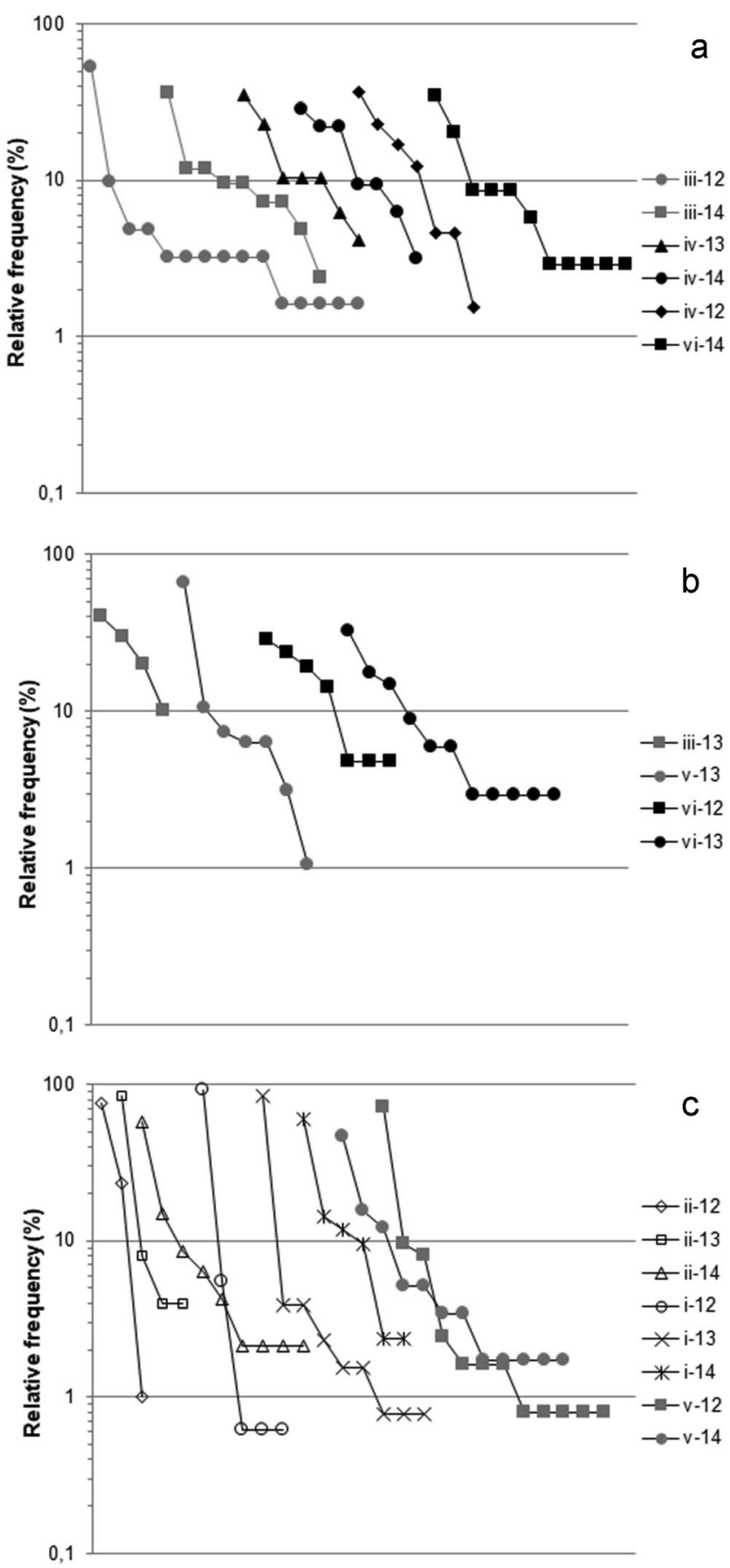

Fig. 5 Dominance rank structures of Orthoptera assemblages (samples) grouped according to the cluster analysis:. a humid, b transitional; c xeric. Colour of markers shows a priory category of sites: black - humid, grey - transitional, white/empty - xeric habitats

\section{Discussion}

The species number of the Orthoptera communities was not lower than expected based on earlier surveys in the Bereg lowland (Nagy et al. 2011; Szanyi et al. 2015b), however, their composition has proved rather one-sided both in life-form and biogeographical types compared with the assemblages of sandy and saline habitats (Rácz 1998a; Nagy et al. 2007b). The bulk of the species composition was formed by generalist chortobiont species $(62.5 \%)$ while the proportion of thamnobionts was essentially lower $(29.1 \%)$ even in the closed well structured humid grasslands $(32.53 \%)$. The geochortobiont, geobiont life forms were represented by only a single species (Aiolopus thalassinus). These traits of the assemblages were the consequence that with exception of xeric ones, all habitats had tall grass, tall forb structures without bare patches. Most assemblages were characterised by a rather imbalanced dominance structure with the presence of one or two dominant species (in xeric sites about $80 \%$ ) and only in some transitional or humid sites also with 3-4 subdominant species.

These grasslands are mostly populated by widely distributed Euro-Siberian (58.3\%) and West Palearctic species and only with scarce occurrence of some few specialists. Therefore the Orthoptera assemblages were subdivided only according to the humidity gradient with some fluctuations connected with the weather conditions of consecutive years and did not show the well-known "horse-shoe" pattern of ordination signing an ecological gradient (Rácz 1998a, 1998b; Varga et al. 2000; Nagy et al. 2007b). From the whole spectrum of species only 15 species fulfilled the pre-conditions of the IndVal analysis. These belonged to the transitional (Conocephalus discolor and Aiolopus thalassinus) or humid (Pholidoptera griseoaptera, Ruspolia nitidula, Mecostethus parapleurus) habitat types. There were no characteristic species for xeric sites. It means that the xeric habitats of this region do not represent true xeric habitats, as some sandy or saline grasslands (see: Nagy and Szövényi 1998; Szövényi and Nagy 1999; Rácz 2001, 2002; Nagy et al. 2007b), but they were mostly influenced by draining and overgrazing.

Since the most diverse assemblages are connected with the semi-natural humid and transitional habitat types surrounded with nature-like scrubby forest fringes, these habitat types should have the highest priority in nature conservation. A parallel survey of butterfly assemblages of this region resulted in the same conclusions (Szanyi et al. 2018). These habitats possibly could be conserved or restored by yearly alternating mowing with uncut refuge stripes (see: Humbert et al. 2010, 2012) and occasionally by selective cutting of extending scrubs (e.g. Prunus spinosa, Rosa spp., Rubus spp.). The xeric habitats can be only used by a rather moderate level of grazing due to the low phytomass production of these sites. At landscape level the conservation of the mosaic structure with some corridors among the more nature-like and semi-natural sites should also have a high importance, considering also the possibilities of the trans-boundary corridors to the Hungarian part of the Bereg lowland which is already a protected landscape area.

Acknowledgments The study was supported by International Visegrad Fund (2015). Szabolcs Szanyi was supported by the Collegium Talentum 2017. 
Funding Open access funding provided by University of Debrecen. The study was supported by International Visegrad Fund: Visegrad Scholarship Program (2015) (Serial Number: 51400476). Szabolcs Szanyi was supported by the Collegium Talentum 2017.

\section{Declarations}

Conflict of interest The authors declare that they have no conflict of interest.

Open Access This article is licensed under a Creative Commons Attribution 4.0 International License, which permits use, sharing, adaptation, distribution and reproduction in any medium or format, as long as you give appropriate credit to the original author(s) and the source, provide a link to the Creative Commons licence, and indicate if changes were made. The images or other third party material in this article are included in the article's Creative Commons licence, unless indicated otherwise in a credit line to the material. If material is not included in the article's Creative Commons licence and your intended use is not permitted by statutory regulation or exceeds the permitted use, you will need to obtain permission directly from the copyright holder. To view a copy of this licence, visit http://creativecommons.org/licenses/by/4.0/.

\section{References}

Andersen AN, Ludwig JA, Mowe LM, Rentz DCF (2001) Grasshopper biodiversity and bioindicators in Australian tropical savannas: responses to disturbance in Kakadu National Park. Austral Ecol 26: 213-222. https://doi.org/10.1046/j.1442-9993.2001.01106.x

Andrén H (1996) Population responses to habitat fragmentation: statistical power and the random sample hypothesis. Oikos 76:235-242. https://doi.org/10.2307/3546195

Baranyi B (2009) Kárpátalja. Dialóg Campus Kiadó, Pécs-Budapest

Báldi A, Kisbenedek T (1997) Orthoptera assemblages as indicators of grassland naturalness in Hungary. Agric Ecosyst Environ 66:121129. https://doi.org/10.1016/S0167-8809(97)00068-6

Baur B, Cremene C, Groza G, Rákosy L, Schileyko AA, Baur A, Stoll P, Erhardt A (2006) Effects of abandonment of subalpine hay meadows on plant and invertebrate diversity in Transylvania, Romania. Biol Conserv 132:261-273. https://doi.org/10.1016/j. biocon.2006.04.018

Bei-Bienko GYa (1950) 10. Prjamokrylye-Orthoptera-i kozhistokrylyeDermaptera. In: Zhivotnyj mir SSSR III. Izdatelstvo Akademii nauk CCCR, Moskva-Leningrad

Csergő AM, Demeter L, Turkington R (2013) Declining diversity in abandoned grasslands of the Carpathian Mountains: do dominant species matter? PLoS One 8:e73533. https://doi.org/10.1371/ journal.pone. 0073533

Deli T, Dobó T, Kiss J, Sümegi P (1995) Hinweise über die Funktion eines Grünen Korridors entlang der Tisza (Theiss) auf Grund der Molluskenfauna. Malakológiai Tájékoztató [Malacological Newsletter] 14:29-32

Deli T, Sümegi P, Kiss J (1997) Biogeographical characterisation of the mollusc fauna on Szatmár-Bereg plain. In: Tóth E, Horváth R (eds) Proceedings of the ,research conservation, management" conference (Aggtelek) 1-5 May 1996, ANP Füzetek Vol I., Aggtelek, pp 123-129

Deli T, Sümegi P (1999) Biogeographical characterisation of SzatmárBereg plain based on the Mollusc fauna. In: Hamar J, Sárkány-Kiss A (eds) The Upper Tisza Valley. Tiscia monograph series, Szeged, pp 471-477

Dufrêne M, Legendre P (1997) Species assemblages and indicator species: the need for flexible asymmetrical approach. Ecol Monogr 67:
345-366. https://doi.org/10.1890/0012-9615(1997)067[0345: SAAIST]2.0.CO;2

Fahrig L (1997) Relative effects of habitat loss and fragmentation on population extinction. J Wildl Manag 61:603-610. https://doi.org/ $10.2307 / 3802168$

Fekete G, Varga Z (2006) Magyarország tájainak növényzete és állatvilága. MTA Társadalomkutató Központ, Budapest

Fielding DJ, Brusven MA (1993) Grasshopper (Orthoptera: Acrididae) community composition and ecological distrubance on southern Idaho rangeland. Environ Entomol 24(6):1432-1441. https://doi. org/10.1093/ee/22.1.71

Fodor I (1999) A Fekete- vagy Szernye-mocsár. Napút, Budapest. http:// www.napkut.hu/naput_1999/1999_09/037.htm. Accessed 14.10. 2019

Gallé L, Gausz J (1968) Data for knowledge the entomology of the upperTisza district (Orthopteroidea and Formicoidea). Tiscia 4:83-11

Gardiner T, Hill J, Chesmore D (2005) Review of the methods frequently used to estimate the abundance of Orthoptera in grassland ecosystems. J Insect Conserv 9:151-173. https://doi.org/10.1007/s10841-005-2854-1

Gálik K, Deli T, Sólymos P (2001) Comparative malacological investigations on the Kaszonyi Hill (NE Hungary). Malakológiai Tájékoztató [Malacological Newsletter] 19:81-88

Hambler C, Speight MR (2004) Extinction rates and butterflies. Science 305:1563. https://doi.org/10.1126/science.305.5690.1563b

Harrison S, Bruna E (1999) Habitat fragmentation and large-scale conservation: what do we know for sure? Ecography 22:225-232. https://doi.org/10.1111/j.1600-0587.1999.tb00496.x

Harz K (1957) Die Geradflügler Mitteleuropas. VEB Gustav Fischer Verlag, Jena

Harz K (1960) Geradflügler oder Orthopteren (Blattodea, Mantodea, Saltatoria, Dermaptera). In: Dahl F (ed) Die Tierwelt Deutschlands und der angrenzenden Meeresteile nach ihren Merkmalen und nach ihrer Lebensweise. 46. Teil. Gustav Fischer, Jena

Henle K, Amler K, Biedermann R, Kaule G, Poschlod B (1999) Bedeutung und Funktion von Arten und Lebensgemeinschaften in der Planung. In: Amler K, Bahl A, Henle K (eds) Populationsbiologie in der Naturschutzpraxis. Ulmer, Stuttgart, pp 17-23

Humbert JY, Ghazoul J, Sauter GJ, Walter T (2010) Impact of different meadow mowing techniques on field invertebrates. J Appl Entomol 134:592-599. https://doi.org/10.1111/j.1439-0418.2009.01503.x

Humbert JY, Ghazoul J, Richner N, Walter T (2012) Uncut grass refuges mitigate the impact of mechanical meadow harvesting on orthopterans. Biol Conserv 152:96-101. https://doi.org/10.1016/j.biocon.2012.03.015

Kis B (1962) Contribupii la cunoa terea subgenului Chorthippus s. str. Din R. P. R. Studia Universitatis Babe - Bolyai. Series Biologia 1: 89-99. [in Romanian]

Kis B (1976) Cheie pentru determinarea ortopterelor din România. Partea I Subord Ensifera Muzeul Brukenthal atiinpele Naturii - Studii i Comunicãri 20:123-166. [in Romanian]

Kis B (1978) Cheie pentru determinarea ortopterelor din România. Partea II Subord Caelifera Muzeul Brukenthal atiinpele Naturii - Studii i Comunicãri 22:233-276. [in Romanian]

Ködöböcz V, Magura T (1999) Biogeographical connections of the carabid fauna (Coleoptera) of the Beregi-síkság to the Carpathians. Folia Entomol Hung 60:195-203

Lakatos G, Dalmay K (1998) A Szernye-mocsár: a Pannon-tenger hírmondója (Ukrajna). Természetbúvár 53(4):32-33. [in Hungarian]

Likovitch IM (1957) Nekotorye dannye o faune prjamokrylykh (Orthoptera) Zakarpatja. [Some data on Orthoptera fauna of Ukrainian Carpathians]. Doklady iSoobshchenia Uzhgorodskogo Universiteta. Seria Biologia 1:61-64. [in Russian]

Likovitch IM (1959) K voprosu o vertikalnom raspredelenii prjamokrylykh (Orthoptera) v Zakarpate [On vertical distribution of Orthoptera in UkrainianCarpathians]. Uzhgorodskiy Gosudarstvennyj Universitet. Nauchnye Zapisky 40:227-238. [in Russian] 
Maas S, Detzel P, Staudt A (2002) Gefährdungsanalyse der Heuschrecken Deutschlands. Verbreitungsatlas, Gefährdungseinstufung und Schutzkonzepte. Bundesamt für Naturschutz, Bonn-Bad Godesberg

Magura T, Ködöböcz V, Tóthmérész B, Molnár T, Elek Z, Szilágyi G, Hegyessy G (1997) Carabid fauna of the Beregi-síkság and its biogeographical relations (Coleoptera Carabidae). Folia Entomol Hung 58:73-82

Magurran AE (1988) Ecological diversity and its measurement. Princeton University Press

May RM, Lawton JH, Stork NE (1995) Assessing extinction rates. In: Lawton JH, May RM (eds) Extinction rates. Oxford University Pres, Oxford, pp 1-24

Morris MG (1969) Differences between the invertebrate faunas of grazed and ungrazed chalk grassland III. The heteropterous fauna J Appl Ecol 6:475-487

Nagy A, Orci KM, Rácz IA, Varga Z (2007a) Hazai gyeptípusok egyenesszárnyúi. In: Forró L (ed) A Kárpát-medence állatvilágának kialakulása. Magyar Természettudományi Múzeum, Budapest, pp 349-356

Nagy A, Sólymos P, Rácz IA (2007b) A test on the effectiveness and selectivity of three sampling methods frequently used in orthopterological field studies. Entomol Fenn 18:149-159 DOI: https://doi.org/10.33338/ef.84392

Nagy A, Orci KM, Rácz IA (2008) Különbözö életforma típusú egyenesszárnyú (Orthoptera) fajok morfometriai vizsgálata. In: Kövics Gy, Dávid I (eds) 13. Tiszántúli Növényvédelmi Fórum előadások - Proceedings. Debreceni Egyetem, Debrecen, pp 141-153

Nagy A, Szanyi S, Molnár A, Rácz I (2011) Preliminary data on the Orthoptera fauna of the Velyka Dobron wildlife reserve (Western Ukraine). Articulata 26(2):123-130

Nagy A, Batiz Z, Szanyi S (2015) Orthoptera fauna of the Hungarian part of the Bereg plain (Northeast Hungary). Bul Inf Soc Lepid Rom 26: 64-80

Nagy B (1991) A természeti környezet és az egyenesszárnyú rovarok (Orthoptera) viszonya Budapest körzetében. Természetvédelmi Közlemények 1(1):69-79

Nagy B, Szövényi G (1998) Orthoptera együttesek a Körös-Maros Nemzeti Park területén. Crisicum 1:126-141

Nagy B (2003) A revised check-list of Orthoptera-species of Hungary supplemented by Hungarian names of grasshopper species. Folia ent hung 64:85-94

Obenberger J (1926) Rovnokřídlý hmyz (Orthoptera a Dermaptera) Republiky Československé. Fauna et Flora Čechoslovenica I, Nakl České Akademie věd aumění, Praha

O'Neill KM, Olson BE, Rolston MG, Wallander R, Larson DP, Seibert CE (2003) Effects of livestock grazing on rangeland grasshopper (Orthoptera:Acrididae) abundance. Agric Ecosys Environ 97(1):51-64

Podani J (1997a) Bevezetés a többváltozós biológiai adatfeltárás rejtelmeibe. Scientia Kiadó, Budapest

Podani J (1997b) SYNTAX 5.1.: a new version of PC and Macinthos computers. Coenoses 12:149-152

Pravdin FN (1978) Ekogeografia nasekomykh Centralnoj Azii. Nauka, Moskva. [in Russian]

Pungur J (1899) Ordo. Orthoptera. In: Fauna Regni Hungariae. Természettud Társ, Budapest, pp 1-16

Rácz I (1998a) Biogeographical survey of the Orthoptera Funa in central part of the Carpathian Basin (Hungary): Fauna types and community types. Articulata 13(1):53-69

Rácz I (1998b) Tiszabercel biomonitoring pilot project quantitative Orthopterological research. Tiscia 31:41-45

Rácz I (1998c) Zoogeographical analysis of the orthoptera fauna from Bükk Mountains (N Hungary). Folia Entomol hung 59:5-16
Rácz IA (2001) Egyenesszárnyú együttesek életforma-spetrumának változása a száraz és félszáraz gyepek struktúrájának függvényében. Állattani Közlemények 86:29-56

Rácz IA (2002) Phytocoenoses and their Orthoptera assemblages. Acta Biol Debrecina 24:39-53

Saunders DA, Hobbs RJ, Margules CR (1991) Biological consequences of ecosystem fragmentation - a review. Conserv Biol 5:18-32

Schmitt T, Rákosy L (2007) Changes of traditional agrarian landscapes and their conservation implications: a case study of butterflies in Romania. Divers Distrib 13:855-862. https://doi.org/10.1111/j. 1472-4642.2007.00347.x

Szanyi S, Katona K, Bernát N, Tamási K, Molnár A (2015a) A Nagydobronyi Vadvédelmi rezervátum (Kárpátalja, Nyugat Ukrajna) gyepeinek flórájáról. Tájökológiai Lapok 13(1):1-8

Szanyi S, Katona K, Rácz IA, Varga Z, Nagy A (2015b) Orthoptera fauna of the Ukrainian part of the Bereg plain (Transcarpathia, Western Ukraine). Articulata 30:91-104

Szanyi S, Nagy A, Varga Z (2018) Diversity and concordance in the composition of butterfly assemblages of the Transcarpathian (Bereg) plain (SW Ukraine). Biologia 73:951-964. https://doi.org/ 10.2478/s11756-018-0102-x

Szövényi G, Nagy B (1999) Szikes és löszpuszta élőhelyek egyenesszárnyú rovar (Orthoptera) együtteseinek összehasonlító elemzése a KörösMaros Nemzeti Park területén. Crisicum 2:115-122

Thomas JA, Telfer MG, Roy DB, Preston CD, Greenwood JJD, Asher J, Fox R, Clarke RT, Lawton JH (2004) Comparative losses of British butterflies, birds and plants and the global extinction crisis. Science 303:1879-1881. https://doi.org/10.1126/science.1095046

Thomas JA (2005) Monitoring change in the abundance and distribution of insects using butterflies and other indicator groups. Philos Trans R Soc B 360:339-357. https://doi.org/10.1098/rstb.2004.1585

Tóthmérész B (1996) NuCoSa: Programcsomag botanikai, zoológiai és ökológiai vizsgálatokhoz. Synbiologia Hungarica 2/1. Scientia, Budapest

Varga Z (1992) Állatföldrajzi szempontból érdekes, védett és veszélyeztetett rovarfajok előfordulása a Beregi-sík szigethegyein. Calandrella 4(1):76-80

Varga Z (1995) Geographical patterns of biological diversity in the Palearctic region and the Carpathian Basin. Acta Zool Acad Sci Hung 41:71-92

Varga Z (1997) Trockenrasen im Pannonischen Raum: Zusammenhang der physiognomischen Struktur und de floristischen Komposition mit den Insektenzönosen. Phytocoenologia 27(4):509-571

Varga Z (2003) A Kárpát-medence állatföldrajza. In: Láng I, Bedő Z, Csete L (eds) Növény, állat, élőhely. Magyar Tudománytár III, Kossuth Kiadó, Budapest, pp89-119

Varga Z, Sipos J, Orci KM, Rácz I (2000) Félszáraz gyepek az Aggtelekikarszton: fitocönológiai viszonyok, egyenesszárnyú rovar- és lepkeegyüttesek. In:Virágh K, Kun A (eds) Vegetáció és dinamizmus. MTA Ökológiai és Botanikai Kutatóintézete, Vácrátót

Warren MS (1997) Conserving Lepidoptera in a changing environment: a perspective from Western Europe. J Insect Conserv 1:1-4

Wenzel M, Schmitt T, Weitzel M, Seitz A (2006) The severe decline of butterflies on western calcareous grasslands during the last 30 years: a conservation problem. Biol Conserv 28:542-552

Whittaker RH (1965) Dominance and diversity in land plant communities. Science 147:250-260

Wilcox BA, Murphy DD (1985) Conservation strategy: the effects of fragmentation on extinction. Am Nat 125:879-887

Publisher's note Springer Nature remains neutral with regard to jurisdictional claims in published maps and institutional affiliations. 